\title{
Effect of Broiler Litter Based Complete Feed Fermentation Time on Nutrient Content and In vitro Digestibility
}

\author{
Kilimpares $\mathrm{NAE}^{1}$, Firzatullah $\mathrm{RZ}^{1}$, Andara DI ${ }^{1}$, Mukodiningsih $\mathrm{S}^{1,2}$ \\ ${ }^{1}$ Department of Animal Science, Faculty of Animal Science and Agriculture, Diponegoro University, Semarang. \\ ${ }^{2}$ Feed Technology Laboratory, Department of Animal Science, Faculty of Animal Science and Agriculture, Diponegoro University, Semarang. \\ E-mail: mukodiningsih@gmail.com
}

(received 03-09-2021; revised 11-02-2022; accepted 14-01-2022)

\begin{abstract}
ABSTRAK
Kilimpares NAE, Firzatullah RZ, Andara DI, Mukodiningsih S. 2021 Pengaruh waktu fermentasi pakan lengkap berbasis litter broiler terhadap kandungan nutrien dan kecernaan in vitro. JITV 26(4):145-151. DOI: http://dx.doi.org/10.14334/jitv.v26i4.2895.

Limbah litter broiler semakin meningkat seiring terjadinya peningkatan populasi ayam broiler, disisi lain kebutuhan pakan ternak ruminansia semakin bertambah sehingga diperlukannya pakan alternatif berupa complete feed berbahan litter. Penelitian bertujuan untuk mengetahui pengaruh lama fermentasi terhadap kandungan nutrisi dan nilai kecernaan complete feed. Penelitian menggunakan Rancangan Acak Lengkap dengan 4 perlakukan dan 5 ulangan, Perlakuan T0 = tidak difermentasi; T1 = fermentasi selama 10 hari; T2 = fermentasi selama 24 hari; T3 = fermentasi selama 38 hari. Parameter yang diamati adalah kandungan nutrisi, VFA, $\mathrm{NH}_{3}$, nilai kecernaan bahan kering dan kecernaan bahan organik secara in vitro menggunakan rumen sapi. Hasil penelitian menunjukkan bahwa complete feed yang difermentasi dengan starter EM4 2,5\% dan probiofeed 5\% selama 38 hari (T3) memberikan pengaruh nyata $(\mathrm{P}<0,05)$ terhadap kandungan nutrisi, kecernaan bahan kering, kecernaan bahan organik, VFA dan $\mathrm{NH}_{3}$ pada complete feed. Perlakuan waktu fermentasi selama 38 hari berpengaruh nyata terhadap kadar abu, lemak kasar, protein kasar, BETN, TDN, kecernaan bahan kering, kecernaan bahan orgnaik, VFA dan $\mathrm{NH}_{3}$ tetapi tidak berpengaruh nyata terhadap kadar air dan serat kasar, sehingga complete feed bisa dijadikan sebagai pakan alternatif ternak ruminansia mudah didapatkan, murah dan bisa mengurangi pencemaran lingkungan.
\end{abstract}

Kata Kunci: Pakan Lengkap, Kecernaan, Fermentasi, Litter, Nutrisi

\begin{abstract}
Kilimpare, NAE, Firzatullah RZ, Andara DI, Mukodiningsih S. 2021. Effect of broiler litter based complete feed fermentation time on nutrient content and in vitro digestibility. JITV 26(4): 145-151. DOI: http://dx.doi.org/10.14334/jitv.v26i4.2895.

Broiler litter waste is increasing as the population of broiler chickens increases, on the other hand the need for ruminant feed is increasing so that alternative feeds are needed in the form of complete feed made from litter. This study was aimed to determine the effect of fermentation time on the nutritional content and digestibility of the complete feed. A completely randomized design with 4 treatments and 5 replications were applied in this study. Treatment $\mathrm{T} 0=$ not fermented; $\mathrm{T} 1=$ fermentation for 10 days; $\mathrm{T} 2$ = fermentation for 24 days; $\mathrm{T} 3=$ fermentation for 38 days. Parameters observed were nutrient content, VFA, NH3, dry matter digestibility and organic matter digestibility in vitro using cow rumen. Results showed that fermention of complete feed with 2.5\% EM4 starter and 5\% probiofeed for 38 days (T3) had a significant effect $(\mathrm{P}<0.05)$ on nutrient content, dry matter digestibility, organic matter digestibility, VFA and NH3. The T3 significantly affected ash content, crude fat, crude protein, BETN, TDN, dry matter digestibility, organic matter digestibility, VFA, and NH3 but had no significant effect on water content and crude fiber. It is concluded that the complete feed could be used as alternative feed for ruminants, and it is easy to obtain, cheap and able to reduce environmental pollution.
\end{abstract}

Key Words: Complete feed, Digestibility, Fermentation, Litter, Nutrient

\section{INTRODUCTION}

As Indonesia's cattle population grows, so does the amount of land needed for cattle grazing pastures. This causes the availability of forage to decrease for meeting the needs of livestock productivity so that alternative feeds are needed to overcome these problems. On the other hand, the broiler farming industry is growing along with the increasing public demand. The number of broiler chicken populations in Indonesia has increased from year to year, namely 2017, 2018, 2019 which amounted to $1,922,636,196$ broiler, 3,137,707,479 broiler, and 3,149,382,220 broiler (Badan Pusat Statistik 2019). The increasing population of broiler chickens is in line with the increase in chicken waste produced, namely litter which will result 
in environmental pollution in the future. Litter is a cage mat on chicken farms that are commonly used to prevent livestock from direct contact with the floor and has a function in heat insulation and absorption of water and ammonia. The components contained in the used litter include excreta, bedding material, feathers, and spilt feed and drinking water, if properly processed will provide benefits to livestock productivity because it has the potential as a source of crude protein with low fiber that can be degraded by the rumen (Elemam et al. 2009)

To overcome litter as a pollutant and lack of forage, it can be done by processing broiler chicken litter waste through a fermentation process. Processing of broiler chicken litter through a fermentation process makes it contain better nutritional value so that it has the potential to be used as an alternative feed for ruminants. This is because broiler litter contains $87.5 \%$ dry matter; crude protein $19.2 \%$; crude fibre $27.1 \%$; extract ether $3.33 \%$; ash $26.0 \%$ and NFE $24.4 \%$ (Akinfala \& Komolafe 2011). Litter also contains minerals such as calcium $(\mathrm{Ca})$, magnesium $(\mathrm{Mg})$, iron $(\mathrm{Fe})$, sulfur $(\mathrm{S})$, manganese $(\mathrm{Mn})$, copper $(\mathrm{Cu})$, zinc $(\mathrm{Zn})$, and chlorine $(\mathrm{Cl})$ derived from broilers manure (Yanuartono et al. 2019). However, in broiler chicken litter there is rice husk, with high crude fibre content. The high crude fibre content affects the organic matter content of rice husks so that it can reduce the level of digestibility of the material when consumed by ruminants (Wijayanti et al. 2012).

Fermentation is a method of processing feed ingredients used to improve the quality of materials through the process of decomposition or overhaul of organic matter carried out under anaerobic or facultative anaerobic conditions using microorganisms (Pamungkas 2011). Fermentation in rice husk litter reduce total pathogenic bacteria such as Enterobacteriaceae, Salmonella sp, Escherichia coli, Campylobacter, and others. Fermentation produce organic acids and bacteriocins a type of protein that inhibit the growth of pathogenic bacteria (Rustan 2013). Processing of broiler litter through the fermentation process has a good role in increasing the nutritional value and digestibility of the material due to the activity of microorganisms during fermentation so that it has the potential to be used as ruminant feed. Complete feed is one strategy for feeding livestock that aims to maximize the distribution of feed nutrients to minimize feed selection in livestock and microbial fluctuations in the rumen (Munawaroh et al. 2015). This study was aimed to examine the effect of different fermentation lengths on the nutritional content and digestibility of complete feed based on broiler chicken litter. Complete feed based on broiler chicken litter with fermentation technology is expected to be an alternative feed for ruminants to overcome livestock waste pollution.

\section{MATERIALS AND METHODS}

This research was conducted in June - September 2021 at the Feed Technology Laboratory, Faculty of Animal Science and Agriculture, Diponegoro University, Semarang. Analysis of nutrient content was carried out at the Laboratory of Nutrition and Feed Science, Faculty of Animal Science and Agriculture, Diponegoro University, Semarang and analysis of bacterial content was carried out at the Medical Laboratory, SMK Theresiana, Semarang.

\section{Materials}

Several materials were used in this study including: broiler litter, Lactic Acid Bacteria starter (EM4), proteolytic, lipolytic and lignocellulolytic bacteria (probiofeed), molasses, urea, salt, mineral mix, rice bran, corn straw, coconut meal, curcuma, aquadest, McDougall solution, pepsin $\mathrm{HCL}$ solution, $\mathrm{CO}_{2}$ gas, indicator methyl red and bromcresol green, $\mathrm{H}_{3} \mathrm{BO}_{3} 4 \%$, $\mathrm{H}_{2} \mathrm{SO}_{4} 0,0055 \mathrm{~N}, \mathrm{Na}_{2} \mathrm{CO}_{3}$ saturated, $\mathrm{H}_{2} \mathrm{SO}_{4} \quad 15 \%$, phenolptalin (PP) $1 \%, \mathrm{NaOH} 0,5 \mathrm{~N}, \mathrm{HCl} 0,5 \mathrm{~N}$, vaseline and cow rumen fluid. Meanwhile, the tools used were trash bags, shovels, latex, masks, disk mill machines, analytical scales, fermenter tubes, water baths, ovens, furnaces, desiccators, Whatman 41 filter paper, oil paper, centrifuges, film tubes, Conway dishes, biuret, statif, leitbeig cooler, glass beaker, erlenmeyer, measuring pipette, micro burette, special distilled flask, destruction flask, scissors, blender, plastic tray, label, stove, and stationery.

\section{Method}

The method used in this research includes research design, preparation stage, complete feed fermentation stage, data collection and data analysis.

\section{Research design}

a completely randomized design (CRD) with 4 treatments and 5 replications was applied in this study. The treatments given were T0: Complete feed not fermented, T1: Complete feed fermented for 10 days, T2: Complete feed fermented for 24 days, T3: Complete feed fermented for 38 days.

\section{Preparation stage}

The preparation stage includes the provision of all equipment and materials to be used in the research. Broiler litter was obtained from a close house chicken 
coop owned by Fadli Farm, located in Kaligading Village, Boja District, Kendal Regency.

\section{Complete feed fermentation stage}

Broiler litter and corn straw were ground individually using a disk mill machine until to size of $\pm 5 \mathrm{~cm}$. Then $50 \mathrm{ml}$ of EM4 (with the number of microbial Lactobacillus casei $1,5 \times 10^{6} \mathrm{cfu} / \mathrm{ml}$, Saccharomyces cerevisiae $1,5 \times 10^{6} \mathrm{cfu} / \mathrm{ml}$, Rhodopseudomonas palustris $\left.1 \times 10^{6} \mathrm{cfu} / \mathrm{ml}\right), 100 \mathrm{~g}$ of probiofeed, $150 \mathrm{ml}$ of molasses, and $0,5 \mathrm{~g}$ of premix were dissolved into a bucket containing $105 \mathrm{ml}$ of water. Then as much as $500 \mathrm{~g}$ of broiler litter, $100 \mathrm{~g}$ of rice bran, $345 \mathrm{~g}$ of corn straw, $50 \mathrm{~g}$ of coconut cake, 50 $\mathrm{g}$ of urea, $50 \mathrm{~g}$ of salt, and $0,2 \mathrm{~g}$ of ginger were put into a bucket and stirred until homogeneously mixed. Furthermore, the litter mixture is watered using a solution that has been made evenly. After thoroughly mixed, all the ingredients are then put into a trash bag and wrapped tightly so that there are no air cavities to create anaerobic fermentation conditions. Trash bags were then labelled according to the treatment (T0, T1, T2 and T3). Furthermore, the fermentation process is stopped by drying in air dry for 3-4 days when the material has undergone a long fermentation according to the treatment. Then the material is finely ground using a disk mill machine to facilitate laboratory testing.

\section{Data collection}

The analysis phase includes proximate analysis, dry matter digestibility (DMD), organic matter digestibility (OMD), VFA and NH3. The proximate analysis includes water content analysis using oven drying method, ash content analysis using ashing method using a furnace, crude protein content analysis carried out using the Kjeldahl method, crude fat content analysis using the Soxhlet method and crude fibre content analysis using the method (AOAC 2005). The DMD and OMD analysis stages were carried out by following the procedure (Tilley \& Terry 1963). Measurement of VFA using steam distillation technique and measurement of $\mathrm{NH} 3$ using the Conway microdiffusion technique (AOAC 2005).

Determination of digestibility and end-product of rumen microbial fermentation was carried out by following the procedure (Tilley \& Terry 1963) by weighing a sample of $0.55-0.56 \mathrm{~g}$ and put into a fermenter tube filled with $40 \mathrm{ml}$ of McDougall's solution and $10 \mathrm{ml}$ of cow rumen fluid. Furthermore, $\mathrm{CO}_{2}$ gas was added for 15-20 seconds to create an anaerobic atmosphere in the fermenter tube and then incubated in a water bath at $39^{\circ} \mathrm{C}$ for 48 hours (every 6 hours shaking was done). After 48 hours of incubation, it was centrifuged at $3000 \mathrm{rpm}$ for 10 minutes. The precipitate obtained was then added to $50 \mathrm{ml}$ of $0,2 \%$ $\mathrm{HCl}$ pepsin solution and incubated again for 48 hours. Then filtered with Whatman 41 filter paper with the help of a vacuum pump and rinsed with $50 \mathrm{ml}$ of distilled water, $50 \mathrm{ml}$ of $\mathrm{H}_{2} \mathrm{SO}_{4}, 50 \mathrm{ml}$ of distilled water and $10 \mathrm{ml}$ of alcohol. The filter results were put into a porcelain crucible and then baked at $110^{\circ} \mathrm{C}$ for 12 hours to calculate the dry matter digestibility. The samples were then kilned at $550^{\circ} \mathrm{C}$ for 6 hours to calculate the digestibility of the organic matter. The dry matter and organic matter digestibility values were calculated using the following formula:

$$
\begin{aligned}
& \mathrm{DMD}=\frac{\text { DM Sample }-(\mathrm{DM} \text { Residue }- \text { DM Blanko })}{\text { DM Sample }} \\
& \mathrm{OMD}=\frac{\text { OM Sample }-(\text { OM Residue }- \text { OM Blanko })}{\text { OM Sample }}
\end{aligned}
$$

Samples for VFA and NH3 analysis were only incubated in a water bath for 3 hours (every 30 minutes shaking). Analysis of total VFA production was carried out using the steam distillation method following the procedure (AOAC 2005). Calculation of total VFA production is calculated by the formula:

Total VFA $=($ blank titration - sample titration $) \times \mathrm{N}$ $\mathrm{HCl} \times \frac{1000}{5} \mathrm{mM}$

Analysis of NH3 production or determination of ammonia levels was carried out using the Conway microdiffusion technique following the procedure (AOAC 2005). Calculation of $\mathrm{NH} 3$ production is calculated by the formula:

$\mathrm{N}-\mathrm{NH}_{3}=\left(\mathrm{ml} \mathrm{H}_{2} \mathrm{SO}_{4}\right.$ titrant $\left.\times \mathrm{N} \mathrm{H}_{2} \mathrm{SO}_{4} \times 1000\right)$ $\mathrm{mM}$.

\section{Data analysis}

The data obtained were analyzed using the Analysis of Variance (ANOVA) to test the diversity of the data and if there was a significant effect, continued with Duncan's Multiple Range Test (DMRT) at a 95\% confidence level.

\section{RESULTS AND DISCUSSION}

\section{Effect of different fermentation time on nutrient content of complete feed}

The results in table 1 show that there is an effect of the time of fermentation on the moisture, ash, crude fat 
Table 1. Chemical composition and nutritional value of complete feed

\begin{tabular}{|c|c|c|c|c|}
\hline \multirow{2}{*}{ Parameter } & \multicolumn{4}{|c|}{ Treatments } \\
\hline & T0 & $\mathrm{T} 1$ & $\mathrm{~T} 2$ & $\mathrm{~T} 3$ \\
\hline & \multicolumn{4}{|c|}{ 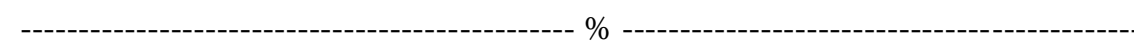 } \\
\hline Water & $10.13 \pm 0.20^{\mathrm{ns}}$ & $9.93 \pm 0.11^{\mathrm{ns}}$ & $10.37 \pm 0.35^{\text {ns }}$ & $10.58 \pm 0.06^{\mathrm{ns}}$ \\
\hline Ash & $25.46 \pm 0.29^{\mathrm{b}}$ & $28.91 \pm 0.35^{\mathrm{a}}$ & $28.47 \pm 078^{\mathrm{a}}$ & $29.42 \pm 0.04^{\mathrm{a}}$ \\
\hline Crude Fat & $1.30 \pm 0.28^{b}$ & $2.61 \pm 0,24^{\mathrm{ab}}$ & $2.92 \pm 0,46^{\mathrm{ab}}$ & $4.13 \pm 1.09^{\mathrm{a}}$ \\
\hline Crude Fibre & $18.21 \pm 0.65^{\mathrm{ns}}$ & $18.76 \pm 1.20^{\mathrm{ns}}$ & $17.66 \pm 0.10^{\mathrm{ns}}$ & $16.91 \pm 1.30^{\mathrm{ns}}$ \\
\hline Crude Protein & $16.01 \pm 0.10^{\mathrm{a}}$ & $12.70 \pm 0.10^{\mathrm{d}}$ & $13.74 \pm 0.10^{c}$ & $14.26 \pm 0.10^{\mathrm{b}}$ \\
\hline Nitrogen Free Extract & $28.89 \pm 0.30^{\mathrm{a}}$ & $27.09 \pm 0.40^{\mathrm{ab}}$ & $26.84 \pm 0.36^{\mathrm{ab}}$ & $24.7 \pm 0.52^{b}$ \\
\hline Total Digestible Nutrient & $65.08 \pm 0.17^{\mathrm{b}}$ & $64.95 \pm 0.24^{\mathrm{b}}$ & $66.35 \pm 0.12^{\mathrm{ab}}$ & $68.06 \pm 0.43^{\mathrm{a}}$ \\
\hline
\end{tabular}

Different superscripts on the same line indicate significant differences $(\mathrm{P}<0.05)$

and crude protein content of the complete feed, while the crude fibre is not affected by the length of fermentation.

Based on table 1. it is known that the length of fermentation treatment did not significantly affect $(P>0.05)$ water content. The results obtained showed an increasing trend with increasing fermentation time, namely with a water content of $10.58 \%$. Researchers suspect this is due to the activity of microorganisms that make the water content in each treatment increase during the fermentation process. According to Hilakore (2008) in the fermentation process, the water content is utilized by microbes for the process of transporting nutrients and metabolite products so that the higher the water content, the higher the microbial activity. This is in accordance with the opinion of Hamid et al. (1999) which states that the high-water content produced in the fermentation process can occur due to the long fermentation time that supports the activity of molds in reforming nutrients as energy formation with byproducts in the form of metabolites, alcohol, acid, $\mathrm{CO}_{2}$ and water.

The long fermentation time had a significant effect $(\mathrm{P}<0.05)$ on increasing the ash content of the complete feed. The increase in ash content from treatment T0 to T3 occurred as a result of a decrease in crude fiber content. According to Aang et al. (2012) the longer the fermentation time will increase the opportunity for microbes to grow so that the activity of microbial enzymes in breaking down complex bonds into simpler molecules becomes higher as well. The increasing number of these activities will result in the reshuffling of organic matter in large quantities, so that the reduction in organic matter can increase the ash content. This is in accordance with the opinion of Irawan et al. (2012) which states that during the fermentation process, microbes digest a lot of organic matter into simple sugars which will then be used by microbes to support their activities so that in the end the degradation of organic matter by microbes will increase. The high ash content indicates that the mineral content is high in the complete fermented feed.

The duration of fermentation treatment on complete feed significantly affected $(\mathrm{P}<0.05)$ fat content. The highest fat content was obtained from the $\mathrm{T} 3$ treatment with a value of 4.13 , while the lowest fat content was obtained from the T1 treatment with a value of $1.30 \%$. These results prove that the longer the fermentation time, the higher the fat content will be. This increase in crude fat content was expected due to an increase in crude protein and a decrease in crude fiber content, causing an increase in the availability of substrates for fatty acid synthesis. This is in accordance with the opinion of Superianto et al. (2018) which states that the fermentation treatment aims to break down complex compounds into simpler ones so that they can be utilized by microbes for their growth as a source of energy in the form of VFA (Vollaile Fatty Acid) in addition to energy from easily digestible carbohydrates. This is supported by the opinion of Saputro et al. (2015) which states that the longer the fermentation time will make the microorganisms continue to grow and develop because of the energy from the high carbohydrate substrate which is converted into fat.

Results of the analysis showed that effect of duration of fermentation on the crude fiber content of the complete feed was not significant $(\mathrm{P}>0.05)$, this was presumably because the length of the fermentation time for each treatment did not provide enough time for microbes to degrade crude fiber in the complete feed. According to Aang et al. (2012) that an increase in the length of fermentation time causes an increase in the opportunity for microbes to grow and ferment, so the longer the fermentation time at a certain time, the higher the chance for microbes to degrade the fermented material. However, seen from the results of the percentage 
decrease in crude fiber content in each treatment, the highest crude fiber content was obtained from treatment T1 with a value of $18.76 \%$, while the lowest fiber content was obtained from treatment $\mathrm{T} 3$ with a value of $16.91 \%$. According to Semaun \& Novieta (2016) that the activity of cellulase enzymes produced by cellulolytic microbes can hydrolyze cellulose into simple compounds. The decrease in crude fiber content during fermentation was due to lignocellulolytic bacteria producing lignocellulase enzymes (lignase, cellulase and hemicellulase) which function to degrade crude fiber. The decrease in crude fiber in complete feed fermentation was due to the activity of the lignocellulase enzyme complex which degrades lignocellulosic compounds into their constituent components. This is supported by Sarkar et al. (2011) which states that lignocellulosic compounds can be completely degraded by the synergistic activity of the lignocellulase enzyme complex produced by certain microbes.

Treatment duration of fermentation showed a significant effect $(\mathrm{P}<0.05)$ on crude protein content in complete feed. The crude protein content in the complete feed continued to increase along with the length of the fermentation process (T1, T2, T3). This increase occurred due to the growth of microorganisms along with the length of the fermentation process as a source of microbial protein. According to Orskov (1988) the production of microbial protein is interrelated with the fermentation process and is supported by the opinion of Syahrulawal et al. (2016), the amount of protein used by microbes to form rumen microbial protein and fermentation of carbohydrates will affect the efficiency of microbial protein synthesis. The protein content in the control treatment (T0) was the highest value, this is presumably because the control treatment did not undergo a fermentation process so that the urea used was not degraded and analyzed as crude protein. According to Sumadi et al. (2017) that not only protein will be analyzed as crude protein but also nitrogen that is not derived from protein (NPN).

Content of Nitrogen Free Extract (NFE) of fermented litter ofT1, T2, and T3 significantly decreased when compared to unfermented litter (T0) $(\mathrm{P}<0.05)$. The decrease in the value of NFE in the fermented litter is thought to be due to the long fermentation time that supports the activity of fermenting microbes in large quantities, causing energy consumption in complete feed for microbial activity to increase. According to Pakpahan et al. (2019), NFE is energy (carbohydrates, sugar, and starch) contained in feed which is needed by microbes for their growth process.

The value of the Total Digestible Nutrient (TDN) content of fermented litter was significantly increased $(\mathrm{P}<0.05)$. The data above shows that the TDN content of fermented litter increases with the length of fermentation time, this is due to an overhaul of crude fiber by starter microbes and produces easily digestible carbohydrates so that the TDN value increases. This is following the opinion of Putri \& Chuzaemi (2021) that the addition of a starter containing high concentrations of bacteria can increase the TDN value due to the degradation process or the reshuffling of complex bonds in large numbers by bacteria to produce easily digestible carbohydrates, and supported by the opinion of Amrullah et al. (2019) that the increase in TDN value occur due to a decrease in crude fiber content caused by microbial activity during the fermentation process, which reduces the fiber content of the substrate so that its digestibility increases.

\section{Effect of different fermentation time on dry matter digestibility, organic matter digestibility, VFA and NH3 complete feed}

The results of the study in table 2 show that there is an effect of fermentation length treatment on dry matter digestibility (DMD), organic matter digestibility (OMD), VFA and NH3 in complete feed. Based on table 2, it is known that the fermentation length for 38 days (T3) showed the highest DMD value of $68.09 \%$ and $\mathrm{T} 1$ treatment had the lowest DMD value of $58.83 \%$. The high DMD value might be due to the long fermentation time using a starter containing lactic acid, proteolytic, lipolytic, lignocellulolytic, and lactobacillus plantarum bacteria so that microbes have the opportunity to grow and accelerate nutrient breakdown in complete feed until the 38th day. According to Nugroho et al. (2020) the more the addition of inoculum, the more complex bonds will be degraded so that the fermentation process can take place quickly in increasing dry matter digestibility. The higher the resulting DMD value indicates the amount of dry matter that was digested by microbes.

Effect of duration of fermentation on OMD ofcomplete feed was significantly different $(\mathrm{P}<0.05)$ among treatments. The OMD value of each treatment of the complete feed is classified as good because this OMD value tends to increase in line with the length of fermentation, from the lowest value of $70.06 \%$ in treatment $\mathrm{T} 0$ to the highest value on day 38 (T3), which is $75,37 \%$. Flachowsky \& Hennig (1990) stated that the OMD of broiler litter was $50-73 \%$. This OMD value describes the amount of nutrient content contained in feed ingredients, in this case, complete feed based on broiler litter can be digested in the digestive system. Based on research by Shahowna et al. (2013) that the value of organic matter digestibility of poultry litter added to feed ranged from 67.35 - 79.79\%.VFA (volatile fatty acid) is the final product of the fermentation process which is the main energy source 
Table 2. Dry matter digestibility, organic matter digestibility, volatile faty acid and $\mathrm{NH}_{3}$ Complete feed

\begin{tabular}{|c|c|c|c|c|}
\hline \multirow{2}{*}{ Parameter } & \multicolumn{4}{|c|}{ Treatments } \\
\hline & T0 & $\mathrm{T} 1$ & $\mathrm{~T} 2$ & $\mathrm{~T} 3$ \\
\hline & \multicolumn{4}{|c|}{ 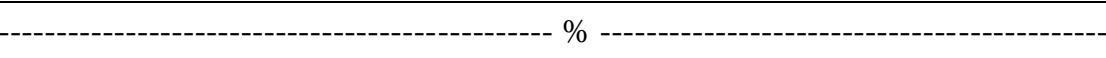 } \\
\hline Dry matter digestibility & $63.44 \pm 1.45^{\mathrm{b}}$ & $58.83 \pm 1.195^{\mathrm{c}}$ & $63.61 \pm 3.765^{\mathrm{b}}$ & $68.09 \pm 0.18^{\mathrm{a}}$ \\
\hline Organic matter digestibility & $70.06 \pm 0.62^{b}$ & $70.41 \pm 0.645^{\mathrm{b}}$ & $73.41 \pm 3.75^{\mathrm{ab}}$ & $75.37 \pm 3.12^{\mathrm{a}}$ \\
\hline Volatile faty acid & $80.00 \pm 10^{c}$ & $50.00 \pm 10^{\mathrm{bc}}$ & $105.00 \pm 5^{\mathrm{ab}}$ & $135.00 \pm 5^{\mathrm{a}}$ \\
\hline $\mathrm{NH}_{3}$ & $9.68 \pm 0.715^{\mathrm{a}}$ & $4.24 \pm 0.495^{\mathrm{b}}$ & $4.81 \pm 0.35^{\mathrm{b}}$ & $5.12 \pm 0.055^{b}$ \\
\hline
\end{tabular}

Different superscripts on the same line indicate significant differences $(\mathrm{P}<0.05)$

for ruminants. The results of the analysis of total VFA production from complete feed showed an increase in VFA value along with the length of fermentation. The highest VFA value was in the T3 treatment, which was $135 \mathrm{mM}$, while the lowest was in the T1 treatment, which was $50 \mathrm{mM}$. Joseph (2020) stated that the normal total VFA production for survival ranges from $80-160$ $\mathrm{mM}$. The increase in total VFA production can occur due to the increase in the fermentation process in the rumen as the fermentation length lasts so that the organic matter in the feed which is degraded by rumen microorganisms also increases and increases the total VFA production. According to Wajizah et al. (2015) that the digestibility value and the quality of the fermented ration will affect the amount of VFA produced.

The long fermentation treatment had a significant effect $(\mathrm{P}<0.05)$ on the production of $\mathrm{NH} 3$. The highest $\mathrm{NH} 3$ production was in the T0 treatment, which was $9.68 \mathrm{mM}$, while the lowest $\mathrm{NH} 3$ production was in the $\mathrm{T} 1$ treatment, which was $4.24 \mathrm{mM}$, while the $\mathrm{T} 2$ and $\mathrm{T} 3$ treatments were not significantly different from the $\mathrm{T} 1$ treatment, which were $4.81 \mathrm{mM}$ and $5.12 \mathrm{mM}$ respectively. The results of the analysis showed that the $\mathrm{NH} 3$ value was quite good, ranging from 4.24-9.68 $\mathrm{mM}$. According to Badarina et al. (2014), the value of good NH3 production for rumen microbial life ranged from 4-12 mM. The high value of $\mathrm{NH} 3$ in the T0 treatment is thought to be because the urea used as a nitrogen source in the manufacture of complete feed has not been degraded by lactic acid bacteria so that the value of the resulting $\mathrm{NH} 3$ test increases.

\section{CONCLUSION}

Based on the results of the study, it is concluded that the recommended fermentation time is 38 days, because it has a better nutritional value and digestibility. The duration of fermentation had a significant effect on the value of ash content, crude fat, crude protein, dry matter digestibility, organic matter digestibility, VFA, and $\mathrm{NH} 3$, but had no significant effect on water content and crude fiber. Complete fermented feed has high dry matter digestibility and organic matter digestibility so that it can be used as an alternative feed for ruminants that is easy to obtain, inexpensive and can reduce environmental pollution.

\section{ACKNOWLEDGEMENT}

The writer expressed his greatest gratitude to all who contributed their best to the research. Respectfully, the writer would like to thank to Direktorat Pembelajaran dan Kemahasiswaan Direktorat Jenderal Pendidikan Tinggi Kementerian Pendidikan, Kebudayaan, Riset dan Teknologi which has provided financial assistance through the Program Kreativitas Mahasiswa (PKM) 2021 and Prof. Dr. Ir. Sri Mukodiningsih, M.S. for her guidance and advice in conducting research, and to the Laboratory of Nutrition and Feed Science, Faculty of Animal Science and Agriculture, Diponegoro University for technical assistance in the use of laboratory facilities.

\section{REFERENCES}

[AOAC] Association of Official Analytical Chemists. 2005. Official methods of analysis. 18th ed. Washington DC (USA): Association of Official Analytical Chemists.

Aang R, Abun, Tjitjah A. 2012. Pengaruh dosis dan lama fermentasi buah ketapang (Ficus lyrata) oleh bacillus licheniformis terhadap kandubgan protein kasar dan lemak kasar. Students e-Journal. 1:1-5.

Akinfala E, Komolafe O. 2011. Evaluation of different processing methods on the nutrient composition of broiler litter and its utilization by weaner pigs in the tropics. Livest Res Rural Dev. 23:1-5.

Amrullah M, Tampoebolon B, Prasetyono B. 2019. Kajian pengaruh proses fermentasi sekam padi amoniasi menggunakan aspergillus niger terhadap serat kasar, protein kasar, dan total digestible nutrients. J Pengemb Penyul Pertan. 16:25-31.

Badan Pusat Statistik. 2019. Populasi ayam ras pedaging menurut provinsi (ekor), 2009-2019. [accessed $2021 \mathrm{Feb}$ 12]. https://www.bps.go.id/linkTableDinamis/view/id/1034. 
Badarina I, Evvyernie D, Toharmat T, Herliyana E. 2014. Fermentabilitas rumen dan kecernaan in vitro ransum yang disuplementasi kulit buah kopi produk fermentasi jamur Pleurotus ostreatus. J Sains Peternak Indones. 9:102-109.

Elemam M, Fadelelseed A, Salih A. 2009. Growth performance, digestibility, N-balance and rumen fermentation of lambs fed different levels of deep-stack broiler litter. Res J Anim Vet Sci. 4:9-16.

Flachowsky G, Hennig A. 1990. Composition and digestibility of untreated and chemically treated animal excreta for ruminants a review. Biol Wastes. 31:17-36.

Hamid H, Purwadaria T, Haryati T, Sinurat A. 1999. Perubahan nilai bilangan peroksida bungkil kelapa dalam proses penyimpanan dan fermentasi dengan Aspergillus niger. JITV. 4:101-107.

Hilakore M. 2008. Peningkatan nutrisi putak melalui fermentasi campuran Trichoderma reesei dan Aspergillus niger sebagai pakan ruminansia. Bogor (indones): IPB University.

Irawan P, Sutrisno C, Utama C. 2012. Komponen proksimat pada kombinasi jerami padi dan jerami jagung yang difermentasi dengan berbagai aras isi rumen kerbau. Animal Agriculture Journal. 1 (2): 17-30.

Joseph G. 2020. Evaluasi kecernaan in-vitro dan kandungan nutrien pada lamtoro mineral blok (lmb) sebagai pakan suplemen untuk ternak ruminansia. J Hutan Pulau-Pulau Kecil. 4:169-203.

Munawaroh L, Budisatria I, Suwignyo B. 2015. Pengaruh pemberian fermentasi complete feed berbasis pakan lokal terhadap konsumsi, konversi pakan, dan feed cost kambing bligon. Bul Peternak. 39:167-173.

Nugroho A, Muhtarudin M, Erwanto E, Fathul F. 2020. Pengaruh perlakuan fermentasi dan amoniasi kulit singkong terhadap nilai kecernaan bahan kering dan bahan organik ransum pada domba jantan. J Ris dan Inov Peternak. 4:119-125.

Orskov E. 1988. Nutrición proteica de los rumiantes/Protein nutrition in ruminants. $2^{\text {nd }}$ ed. San Diego (USA): Academic Press Inc.

Pakpahan P, Irjon R, Pujaningsih W. 2019. Evaluasi komposisi nutrien kulit ubi kayu dengan berbagai perlakuan sebagai bahan pakan kambing lokal. J Pengemb Penyul Pertan. 15:49-57.

Pamungkas W. 2011. Teknologi fermentasi, alternatif solusi dalam upaya pemanfaatan bahan pakan lokal. Media Akuakultur. 6:43-48.

Putri GRA, Chuzaemi S. 2021. Level penggunaan Aspergillus oryzae pada fermentasi kulit ubi kayu (Manihot utilissima) terhadap kandungan HCN, TDN dan pH. J Nutr Ternak Trop. 4:60-69.
Rustan I. 2013. Studi isolasi and identifikasi bakteri asam laktat dari fermentasi cabai rawit (Capsicum frutencens L.): Makassar (indones): Hasanuddin University.

Saputro R, Fathul F, Widodo Y. 2015. Pengaruh lama fermentasi dengan media Trametes $\mathrm{Sp}$. terhadap organoleptik, kadar air, dan lemak pada limbah daun nenas di Lampung tengah. J Ilm Peternak Terpadu. 3:68-74.

Sarkar P, Meghvanshi M, Singh R. 2011. Microbial consortium; a new approach in effective degradation of organic kitchen waste. Int J Environmenmtal Sci Dev. 2:170-174.

Semaun R, Novieta I. 2016. Analisis kandungan protein kasar dan serat kasar tongkol jagung sebagai pakan ternak alternatif dengan lama fermentasi yang berbeda. J Galung Trop. 5:71-79.

Shahowna E, Mahala A, Mokhtar A, Amasaib E, Attaelmnan B. 2013. Evaluation of nutritive value of sugar canebagasse fermented with poultry litter asanimal feed. African J Food Sci Technol. 4:106-109.

Sumadi S, Subrata A, Sutrisno S. 2017. Produksi protein total dan kecernaan protein daun kelor secara in vitro. J Sain Peternak Indones. 12:419-423.

Superianto S, Harahap A, Ali A. 2018. Nilai nutrisi silase limbah sayur kol dengan penambahan dedak padi dan lama fermentasi yang berbeda. J Sain Peternak Indones. 13:104-111.

Syahrulawal L, Rianto E, Arifin M. 2016. Kondisi cairan rumen serta produksi protein mikroba pada Sapi Madura jantan yang diberi complete feed dengan jumlah berbeda. Semarang (Indones): Diponegoro University.

Tilley J, Terry R. 1963. A two stage technique for the in vitro digestion of forage. J Br Grassl Soc. 18:104-111.

Wajizah S, Samadi S, Usman Y, Mariana E. 2015. Evaluasi Nilai Nutrisi dan Kecernaan In vitro Pelepah Kelapa Sawit (Oil Palm Fronds) yang Difermentasi Menggunakan Aspergillus niger dengan Penambahan Sumber Karbohidrat yang Berbeda. J Agripet. 15:1319.

Wijayanti E, Wahyono F, Surono. 2012. Kecernaan nutrien dan fermentabilitas pakan komplit dengan level ampas tebu yang berbeda secara in vitro. Anim Agric J. 1:167179 .

Yanuartono Y, Nururrozi A, Indarjulianto S, Haribowo N, Purnamaningsih H, Raharjo S. 2019. Manure unggas: suplemen pakan alternatif dan dampak terhadap lingkungan. J Bioteknol Biosains Indones. 5:241. h 